\title{
Exploring Openness and Connectedness During Online Learning
}

Nor Suziwana Tahir, Yarina Ahmad, Siti Nur Fathanah Abdul Hamid, Nor Ezatie Mukminah Muhammad Zamri, Abdul Razak Arsat, Noor Hanim Rahmat

To Link this Article: http://dx.doi.org/10.6007/IJARBSS/v11-i11/11683 DOI:10.6007/IJARBSS/v11-i11/11683

Received: 04 September 2021, Revised: 06 October 2021, Accepted: 01 November 2021

Published Online: 26 November 2021

In-Text Citation: (Tahir et al., 2021)

To Cite this Article: Tahir, N. S., Ahmad, Y., Hamid, S. N. F. A., Zamri, N. E. M. M., Arsat, A. R., \& Rahmat, N. H. (2021). Exploring Openness and Connectedness During Online Learning. International Journal of Academic Research in Business and Social Sciences, 11(11), 2395-2409.

Copyright: (C) 2021 The Author(s)

Published by Human Resource Management Academic Research Society (www.hrmars.com) This article is published under the Creative Commons Attribution (CC BY 4.0) license. Anyone may reproduce, distribute, translate and create derivative works of this article (for both commercial and non0-commercial purposes), subject to full attribution to the original publication and authors. The full terms of this license may be seen at: http://creativecommons.org/licences/by/4.0/legalcode

Vol. 11, No. 11, 2021, Pg. $2395-2409$

Full Terms \& Conditions of access and use can be found at http://hrmars.com/index.php/pages/detail/publication-ethics 


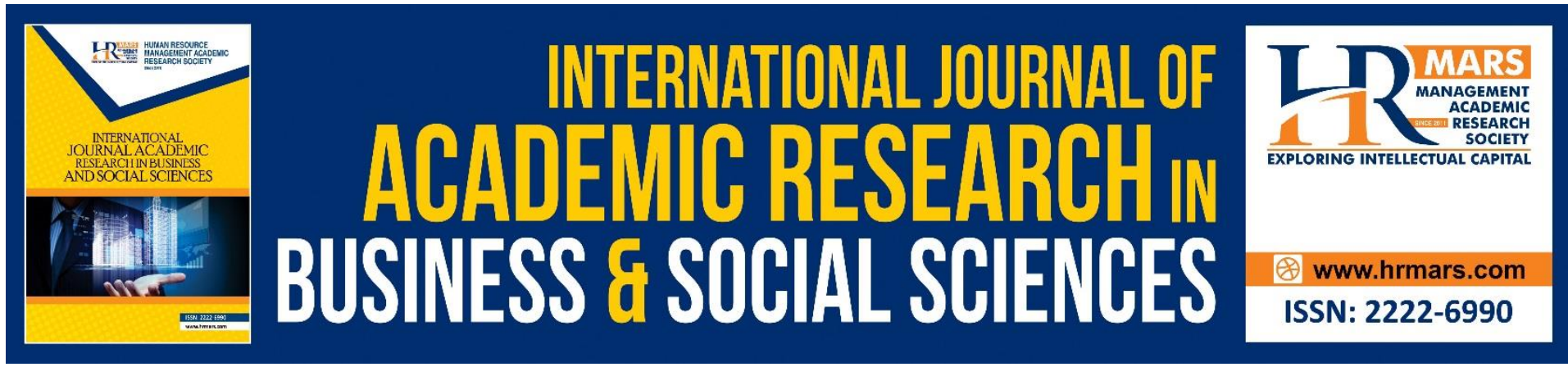

\title{
Exploring Openness and Connectedness During Online Learning
}

\author{
Nor Suziwana Tahir, Yarina Ahmad², Siti Nur Fathanah Abdul \\ Hamid $^{3}$, Nor Ezatie Mukminah Muhammad Zamri ${ }^{4}$, Abdul \\ Razak Arsat $^{5}$, Noor Hanim Rahmat ${ }^{6}$ \\ 1,2,3,4 Faculty of Administrative Science and Policy Studies, Universiti Teknologi MARA, Shah \\ Alam, Selangor, ${ }^{5}$ Quba Engineering Sdn Bhd, ${ }^{6}$ Akademi Pengajian Bahasa, Universiti \\ Teknologi MARA Cawangan Johor, Kampus Pasir Gudang \\ Email: suziwana@uitm.edu.my
}

\begin{abstract}
Covid-19 pandemic has accelerated the need for open and distance learning (ODL). Past studies investigate the perception of ODL based on learner-to-learner engagement, leanerto-instructor engagement and learner-to-content engagement. Nevertheless, lack of study conducted to explore ways to boost students' motivation during ODL. This study is necessary to investigate strategies to boost students' motivation during ODL. By exploring the openness and connectedness of the students during ODL, it gives significant information to the instructors and learners. The findings of this study assist the instructors in developing meaningful learning content, establish high engagement with the learner and learners will discover that a good relationship with their peers makes them more motivated during ODL. . To answer the research questions, quantitative method was employed. Instrument is developed from the past literatures to find out how openness and connectedness is displayed during ODL65 undergraduate and postgraduate students responded to online close-ended questionnaire. Findings demonstrate that students perceived that high level of openness during ODL is demonstrated by learner-to-learner engagement and leaner-to-instructor engagement. Meanwhile, connectedness is displayed in ODL through learner-to-content engagement. Also, the students put learner-to-learner engagement as top factor to enrich openness during ODL and eventually boost their motivation. By referring to the findings, it is suggested that future research investigate more efforts and initiatives to establish and sustain openness and connectedness in online learning. The globalization process has made Internet as an essential medium to almost all aspects including professional and personal networks to provide information sources, news and learning materials
\end{abstract}

Keywords: Openness, Connectedness, Learner-To-Learner Engagement, Learner-To-Instructor Engagement, Learner-To-Content Engagement

\section{Introduction}

Nowadays, the face-to-face classroom is starting to lose its monopoly as the learning place for the students and instructors. The globalization process has made Internet as an essential 
medium to almost all aspects in our lives ranging from a global economy, professional and personal networks to provide information sources, news and learning materials. It is undeniable that Internet has made the open and distance learning (ODL) possible. Soetan, Udoh and Suleiman (2015) defined ODL as the educational approach designed to engage students in their homes, whereby the learning process takes place without attending physical classes, no matter where or when they want to study. From this statement, it can be perceived that ODL is an innovative approach of learning and is considered as independent learning because the physical separation between the students and lecturers occurs.

On the other hand, Allam et al (2020) posit ODL is a teaching approach by fully utilising the internet network whereby the students can complete their studies anywhere because the they can access the lectures easily through laptops or smartphones. Also, Hashim et al. (2020) opined that there are various stable and free platforms available for the lecturers and students such as Google Classroom, Google Meet, webinars, TutorRoom and Microsoft Teams to communicate, discuss and conduct the lectures. Another literature referred ODL as elearning. Ogirima et al (2020) elucidate ODL as alternatives in disseminating education and the teaching, learning and research process is conducted by utilising numerous types of electronic media, educational technology and information and communication technology (ICT). For literature, it is evident that the backbone of open and distance learning is the effectiveness of ICT tools to ensure the lecturers and students keep connected.

The global spread of Covid-19 pandemic witnessed the exponential growth of ODL practices as the lecturers and students are required to stay at home and recommence the online learning completely. These new norms in education environment demands the students and lecturers to amplify their ICT skills and some of them feel disinclined to face with this new normal. Aziz et al (2020) conducted a quantitative study to explore challenges faced by students towards ODL during Covid-19. The study discovered that students have negative perceptions of the learning process through ODL because they face difficulty to communicate in completing all assigned tasks. Other challenges of ODL reported by Sari and Nayir (2020) are difficulties in internet access, insufficient knowledge and experience about ODL and students' attitude such as lack of motivation.

In underdeveloped countries, Adnan and Anwar (2020) argue that ODL unable to give satisfactory results as majority of students had low acceptance level due to poor access to the internet connection. They do not only face this technical problem; at the same times the monetary issues also hinder them to obtain better networking services. Chung, Noor and Mathew (2020) revealed that students perceived ODL is challenging to them due to several constraints such as poor internet connection, limited mobile data, no personal computer and lack of technical skills. Some students explicate that ODL only have little impact and agreed that they demand more guidance and time to adapt with the learning. It can be concluded that sustaining students' enthusiasm and keeping them engaged in each ODL session would be a challenge despite the novelty of ODL to cater this new norm.

\section{Statement of Problem}

It is necessary to explore the level of motivation among the students during ODL. Past studies associated the high motivation among the students makes them satisfied with what they have learnt. Rahmat et al (2021) (2021) conducted a study among 34 students from 
undergraduates and postgraduates to investigate the perceived online learning motivation and satisfaction among the students. The findings revealed that the success or failure of online learning is depend on how students perceive the learning experience. The researchers postulate that when the students perceived the learning content is relevance to their study programme, they will have high motivation to explore more. Hence, the more the students identify the relevance, they will be more confidence to apply the knowledge to cater to their needs. This confidence grows the students' satisfaction with the online learning experience.

Studies also discovered that motivation influences and is influenced by the participation of students in ODL. For instance, De Barba et al (2016) investigate the relationship between motivation, online participation behaviors and learning performance. The study concluded that motivation influenced and was influenced by students' participation and this indirectly gives impact on final grade. Also, students who have higher scores on the intrinsic motivation, participate actively in ODL (Giesbers et al., 2013). In placing more emphasis, Li and Tsai (2016) conduct a quantitative study among 59 computer science students participated in an online mobile phone programming course. The findings discovered that students who intensively used all the learning materials had higher motivation in terms of intrinsic goal orientations and self-efficacy. In addition, the researchers highlight those students who infrequently used any learning material tend to have lower performance.

Past studies also debated the demotivation among students. Several factors that demotivate students were identified which are ineffective teaching approach, learning difficulty, negative attitude of classmates, personal problem, test anxiety and failure experiences (Adnan, 2020; Irawan et al., 2020). Santosa and Riady (2021) execute a study to explore demotivating factors among English as a Foreign Language learners. 368 undergraduate students participate in this study. The survey divided into several sections; course books, inadequate school facilities, test scores, noncommunicative methods and teachers' competence and teaching style. The study revealed that the absence of teacher in face-to-face classroom associated with low motivation in learning English. Hence, it reduces learners' eagerness to learn English.

Ramlan et al (2021) carried out research to find out the online learning challenges in Malaysian higher education setting during Covid-19. In local context, the researchers state that lack of motivation reported to be one of the challenges of ODL. The students confess that they feel less motivated and less enthusiastic if they perceived the class is not interesting and the presence of external disturbances. Due to lack of motivation, they tend to lose interest in learning and it also impacts the students' emotional stability. These evidences portray that student must have self-motivation and determination for ODL. This is necessary for acquisition of knowledge, skill and good performance. There is a need to find out the solutions to help the students who are lack of motivation in experiencing ODL to give students meaningful online learning experience. Ismail and Razak (2021) study the challenges of learning programming subject in ODL recommends future researchers to conduct a study on how to boost students' motivation during ODL.

Hence, this study is done to investigate openness and connectedness in online learning. Specifically, this study is done to answer the following questions;

(1) RQ1- How is openness displayed in online learning?

(2) RQ2- How is connectedness displayed in online learning? 


\section{Literature Review \\ Openness in online learning}

Choudhury (2018) refers openness in online learning to the accessibility of knowledge in terms of courses, learning materials and evaluation. It can be described as the availability of these resources without any economic, social, legal and technical barrier. Since the ODL signifies that most of the teaching is conducted by someone who are physically away from the learners, it is essential to facilitate the openness in ODL system in more powerful way to enrich the learning experiences. Maphosa and Bhebhe (2020) discuss the concept of openness in ODL. The discussion on openness concept mainly focused on targeted potential students and entry requirements in ODL institutions, openness to teaching and learning approaches, openness in communication and the flexibility of assessment.

Openness in ODL aims to remove the barriers to learning. This aligns with the main purpose of ODL in which to offer educational opportunities to students who could not have access to the traditional and conventional face-to-face class. The openness for entry requirements in ODL can be witnessed through allowing the students to use prior learning and work experience as entry requirements if they unable to meet the minimum entry requirements (Maphosa \& Bhebhe, 2020). Also, ODL institutions are mandated to put great efforts to demonstrate a fully integrated ODL system with appropriate approaches for developing learning contents and providing continuous guidance to learners and instruction to enhance openness in the programme (Maphosa \& Bhebhe, 2020). In addition, meaningful communication between the students and lecturers is crucial to reduce feelings of isolation among the learners (Maphosa \& Bhebhe, 2020). It is also significant to create a fruitful ODL session and bridge the gap between the students and institutions. Therefore, in order to enrich openness in ODL, there is a need to have quality assurance management to measure the achievement of openness in ODL.

\section{Connectedness in Online Learning}

Student interaction in the learning process has been challenged with the shift of face-to-face class to ODL approaches due to the Covid-19 pandemic. Subsequently, the students have pointed out that they experience psychological distance feelings, loneliness, isolation and disconnection from their classmates and education institutions (Arslan, 2021). Arslan (2021) has revealed that connectedness moderates the effects of isolation and loneliness. This evidence postulates that encourage connectedness via alternative methods is paramount to ensure students feel a sense of control over their socialisation, learning and assessment. It is recommended for the learning providers to ensure the digital teaching resources establish student connectedness in order to alleviate challenges they faced during ODL. For instance, an effective digital resource must be accessible to all students and convenience to use. This is because Stone and Springer (2019) found that accessibility issues with digital resources can be one of the barriers to connectedness.

Also, Stone and Springer (2019) showed that teacher presence can increase the connectedness in ODL. Students perceived that the learning environment is supportive, engaging and inclusive when the teachers continuously taking care the student-teacher relationships. For example, students tend to feel connected when the lecturers recognised their individual abilities and regularly engage in meaningful communication. Also, the higher perceived professionalism of the teachers correlated with greater student connectedness 
(Martin, Wang \& Sadaf, 2018). The teachers can develop an active interaction and participation in discussion compared to passive teaching (Hehir et al., 2021). Literatures posit that the teacher presence in combination with regular and engaging course content in remote learning is vital for student connectedness.

\section{Past Studies}

Past Studies in Disadvantages of online learning

Past studies also looking at the drawbacks on ODL. In local context, a quantitative study was carried out by Chea and Huan (2015) to understand the attributes that are mostly valued by ODL learners when choosing an ODL higher education institutions in Malaysia. A total of 320 learners responded to the survey. The researchers managed to discover the drawback of ODL which is losing the human interaction between the lectures and students during teaching and learning. Furthermore, ODL is ideal for self-directed learning; therefore, it is vital for the students to have a high independent level in learning. Otherwise, the students will not be able to complete all the assigned tasks and will be left with a mixed up feeling of disoriented and confused. It can be perceived that the students must have a high degree of self-efficacy to survive in ODL.

Another disadvantage reported by Yu's (2015) study is the difficulty in interacting with peers. Due absenteeism of face-to-face activities, there will be lacking of teamwork and communication skills among the students (Wahab et al., 2019). For example, the interaction issues happened during discussing the group assignment. The disadvantaged students who do not live in big cities might experience problems in term of connectivity, network system and accessibility. Consequently, they might be left behind from the group discussion and cannot give full commitment to the assignment. To support this evidence, Ali et al. (2021) distribute a survey comprised of closed questions to 100 students to gather students' perception on the implementation of ODL. The researchers adapted the questionnaire from the Davis Technology Acceptance Model (TAM) to address the issue of students' perceived usefulness and ease of use of the ODL. The findings of the study revealed several disadvantages mentioned by the students which are ODL language barrier, difficult ODL task, poor internet connection, technological problem and improper interactions.

\section{Past Studies on Advantages of Online Learning}

Despite many disadvantages of ODL rampantly debated in the past studies, some researchers interested to investigate what are the advantages of ODL. Fauziah (2015) enthusiastic conducting focus group interviews and distributing open-ended questionnaires to understand online learning conveniences from the perception of both science physics students and preservice science teachers. The participants from the study opined that online learning has provided a useful method to learn as they just have to click to get any kind of information they wish to know. They also highlight the transition process from the technology to knowledge acquisition. This is perhaps the students use online platforms to search for information as there is a massive amount of information available in the Internet.

Arkorful and Abaidoo (2014) review past literatures to provide a scholarly background on the advantages and disadvantages of ODL adoption in higher educational institutions. The researchers come out with several disadvantages of ODL after analysing the past studies. ODL is considered as an education approach that makes the students undergo contemplation, 
remoteness, as well as lack of interaction or relation. Hence, it demands the students to have a strong self-efficacy and time management skills to reduce such effects. Also, relating to clarifications, offer of explanations and interpretations, ODL method might be unsuitable compared to face-to-face method.

Finally, Sim et al (2021) keen to know the factors that facilitate the ODL among university students in Sarawak. The researchers developed questionnaire to scrutinise students' perception on benefits they gained from ODL. The students acknowledged that ODL manages to develop interpersonal and socialising skills, enhanced family ties and time flexibility. A total of 65 respondents opined that they managed to develop their interpersonal skills by easily socialising and discussing certain issues with their peers. They perceived that with ODL, it strengthens the relationship with their family members and they have more time flexibility in learning. These factors seem to be the top benefits of ODL which eventually lead to high satisfaction among the students.

\section{Conceptual Framework}

Studies have shown that online can bring numerous benefits to learners. According to Wahid et al (2020), learners can benefit from online learning if there are online activities that encourage engagements. In line with the digital age and online learning, Siemen (2005) presented connectivism as a theory in online learning. The four principles for learning (figure 1) according to Siemen (2005) are autonomy, connectedness, diversity, and openness. In online learning; firstly, learners need to have autonomy over their own learning. Next, they need to feel connected through the online activities. Next, to sustain learners' motivation towards online learning, there should be a diversity of teaching methods and materials by the teacher. Finally, learners need to feel that their opinion matters through the openness of the communication

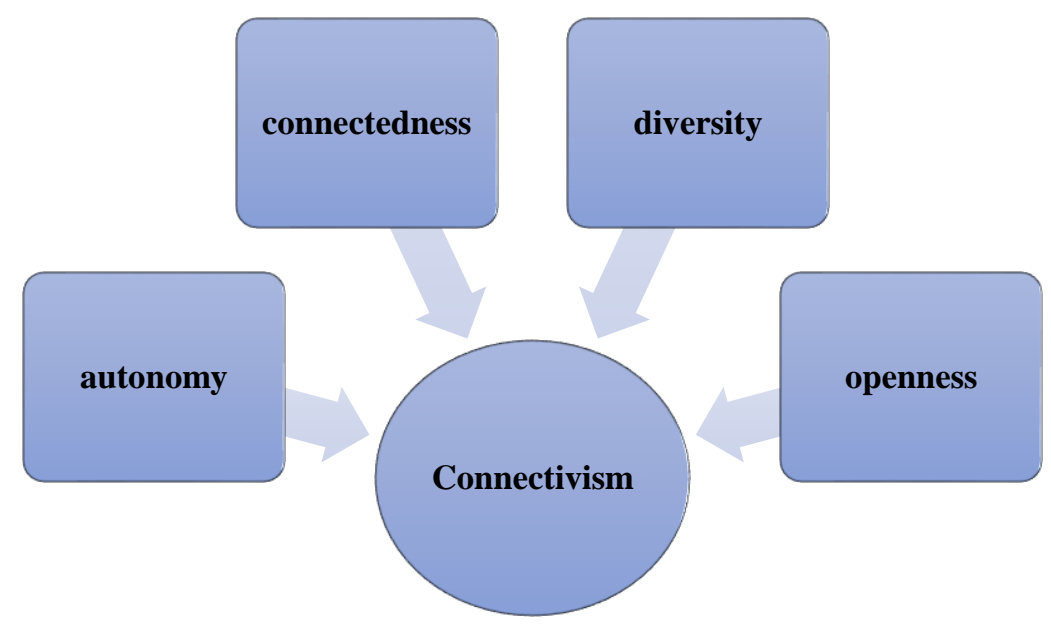

Figure 1- Connectivism (Source: Siemen, 2005)

Hence, this study is rooted on the theory of connectivism (Siemen, 2005) and online engagement by (Martin and Bolliger, 2018). However, in the context of this study (refer to figure 2), only Openness and connectedness are used as the base of the framework. Openness is achieved through learner-to-learner engagement and learner-to-instructor engagement. Next, connectedness can be achieved through learner-to-content engagement. 


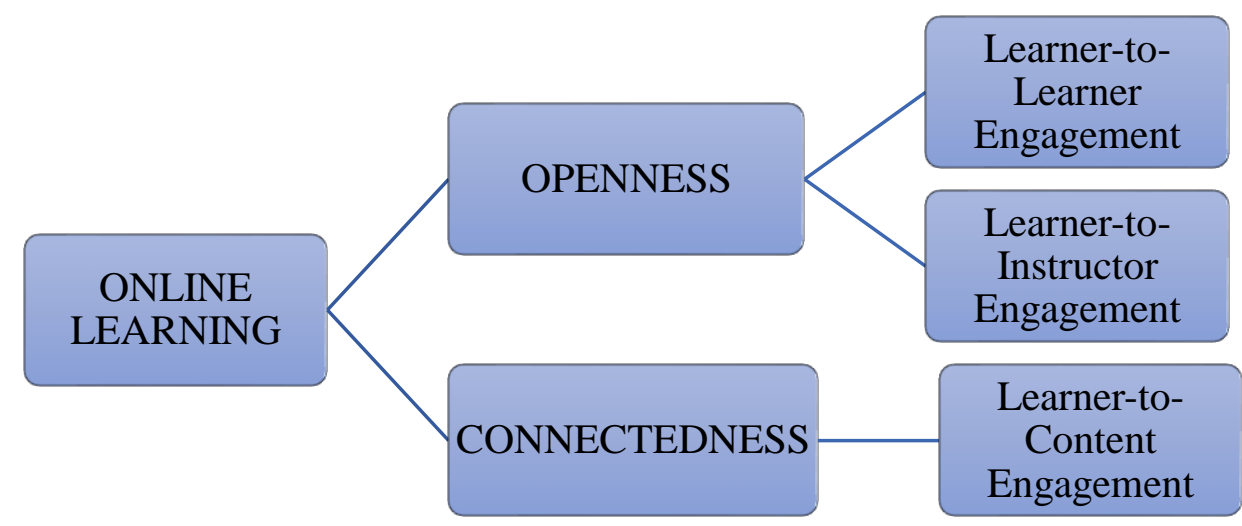

Figure 2- Conceptual Framework of the Study

(Source: Siemen, 2005 \& Martin and Bolliger, 2018)

\section{Methodology}

To answer the research questions of this study, a quantitative approach was employed. This study utilised a questionnaire which comprised of four sections. A random sample of 65 students from undergraduates and postgraduates who experienced ODL were chosen as respondents for this study. Section $A$ of the questionnaire aims to gather the demographic profile of the respondents. Section B focuses on learner-to-learner engagement which consist of 6 items. Next, Section $C$ listed 7 items related to learner-to-instructor engagement. Finally, Section $D$ requests the respondents' opinion on learning-to content engagement. The selfadministered survey was distributed through online by using Google Forms. The data collected from the survey were analysed using descriptive statistic (mean, frequency counts and percentage). The development of the items used in the instrument was adopted from Martin and Bolliger (2018) in which the researchers investigate the perception of ODL based on learner-to-learner engagement, leaner-to-instructor engagement and learner-to-content engagement. As shown in Table 1, the Cronbach's Alpha for 22 items is 0.927, which indicates a high level of internal consistency for the scale.

Table 1: Reliability Test for all items on learner-to-learner engagement, leaner-to-instructor engagement and learner-to-content engagement

\begin{tabular}{ll}
\hline Cronbach's Alpha & N of Items \\
\hline 0.927 & 22
\end{tabular}

\section{Findings}

\section{Findings for Demographic Profile}

A total of 65 respondents responded to this online survey. Out of 65 respondents, $22 \%$ of them are male and $78 \%$ are female. In terms of discipline, majority of respondents, $72 \%$ were from social sciences discipline. $9 \%$ of them from business discipline and $5 \%$ come from others discipline. A small percentage, $4 \%$ are from science $\&$ technology discipline. More than half of the respondents were undergraduates, $57 \%$ while the rest $43 \%$ are postgraduates. 
Table 2: Demographic Profile of Respondents

\begin{tabular}{|c|c|c|c|}
\hline Characteristics & & Frequency (No.) & $\begin{array}{l}\text { Percentage } \\
\text { (\%) }\end{array}$ \\
\hline \multirow[t]{2}{*}{ Gender } & Male & 14 & 22 \\
\hline & Female & 51 & 78 \\
\hline \multirow[t]{5}{*}{ Discipline } & Science & 4 & 6 \\
\hline & Technology & & \\
\hline & Social Sciences & 47 & 72 \\
\hline & Business & 9 & 14 \\
\hline & Others & 5 & 8 \\
\hline \multirow[t]{2}{*}{ Level of Study } & Undergraduate & 37 & 57 \\
\hline & Postgraduate & 28 & 43 \\
\hline
\end{tabular}

\section{Findings for RQ 1}

How is openness displayed in online learning? In the context of this study, openness refers to (a) learner-to-learner and (b) learner-to-instructor engagement.

Learner-to-learner engagement

The mean score was measured using the Mean Score Interpretation designed by Nunally and Berstein (1994) as shown in Table 3. Results were reported accroding to the research questions.

Table 3: Mean Score Interpretation Table (Nunnally and Berstein, 1994)

\begin{tabular}{ll}
\hline Mean Scale & Level \\
\hline $1.00-2.00$ & Low \\
$2.01-3.00$ & Medium Low \\
$3.01-4.00$ & Medium High \\
$4.01-5.00$ & High \\
\hline
\end{tabular}

This study posits that openness displayed in online learning through learner-to-learner engagement. The results showed a high level of openness in online learning is displayed through learner-to-learner engagement. This is portrayed in Table 4 which demonstrated a high mean score of 4.4 for the learner-to-learner engagement. As evident in Table 4, among the items for learner-to-learner engagement, Item 5 "Do you think support from peers motivates you to finish tasks?" ranked the highest mean score with 4.6. Meanwhile, Item 1 "Does collaborative learning promote peer-to-peer understanding?" ranked the lowest mean score with 4. 
Table 4: Mean Score of Learner-to-Learner Engagement Items

\begin{tabular}{ll}
\hline Statement & Mean \\
\hline L2L Q1 Does collaborative learning promote peer-to-peer understanding? & 4
\end{tabular}

L2L Q2 Are you more likely to ask for help from your peers?

L2L Q3 Do you prefer to be in the same group with your chosen peer for online 4.5 activities?

L2L Q4 Do you think that the sense of community helps you to engage in online 4.3 class?

L2L Q5 Do you think support from peers motivates you to finish tasks?

L2L Q6 Do you think that support from peers prevent you from dropping out of 4.5 course?

\section{Learner-to-Instructor Engagement}

In addition, openness displayed in online learning through learner-to-instructor engagement. The results showed a moderate high level of openness in online learning is displayed through learner-to-instructor engagement. This is portrayed in Table 5 which demonstrated a moderate high mean score of 3.9 for the learner-to-instructor engagement. As evident in Table 5, among the items for learner-to-instructor engagement, Item 1 "Does your instructor's teaching style involve students' active participation?" ranked the highest mean score with 4.1. Meanwhile, Item 8 "Do you think ODL promotes greater participation and interaction among learner and instructor?" ranked the lowest mean score with 3.5.

Table 5: Mean Score of Learner-to-Instructor Engagement Items

\begin{tabular}{ll}
\hline Statement & Mean \\
\hline L2I Q1 Does your instructor's teaching style involve students' active participation? & 4.1 \\
\hline L2I Q2 Do you feel encouraged by your instructor to keep engaged in online classroom? & 4 \\
\hline L2I Q3 Does your instructor provide feedback from your previous assessment? & 3.8 \\
\hline $\begin{array}{l}\text { L2I Q4 Do you feel feedback from your instructor on your performances are clear and } \\
\text { positive? }\end{array}$ & 3.8 \\
\hline $\begin{array}{l}\text { L2I Q5 Does your instructor use more than two communication tools to stay connected } \\
\text { with students? }\end{array}$ & 3.9 \\
\hline $\begin{array}{l}\text { L2I Q6 Do you think that online platforms used by your instructor for your online class } \\
\text { are effective and convenient? }\end{array}$ & 3.9 \\
\hline $\begin{array}{l}\text { L2I Q7 Does your instructor maintain the ongoing interaction with students after online } \\
\text { class? }\end{array}$ & 3.8 \\
\hline $\begin{array}{l}\text { L2I Q8 Do you think ODL promotes greater participation and interaction among learner } \\
\text { and instructor? }\end{array}$ & 3.5 \\
\hline Average Mean & 3.9 \\
\hline
\end{tabular}

Findings for RQ 2: How is connectedness displayed in online learning? Connectedness can be achieved through learner-to-content engagement. 
Finally, this study proposes connectedness in online learning is displayed through learner-tocontent engagement. The results showed a moderate high level of connectedness in online learning is displayed through learner-to-content engagement. This is portrayed in Table 6 which demonstrated a moderate high mean score of 4 for the learner-to-content engagement. As evident in Table 6, among the items for learner-to-content engagement, Item 6 and Item 7 "Do you feel that the ease of online content is important?" and "Do you feel that it is important to get an overview of the content before the class begins?" ranked the highest mean score with 4.2 respectively. Meanwhile, Item 2 "Do you think that the asynchronous activities (i.e. assignment) could offer immediate assistance?" ranked the lowest mean score with 3.7.

Table 6: Mean Score of Learner-to-Content Engagement Items

\begin{tabular}{ll}
\hline Statement & Mean \\
\hline L2C Q1 Do you think that the synchronous activities (i.e. online discussion) could & 3.8 \\
offer immediate assistance? &
\end{tabular}

L2C Q2 Do you think that the asynchronous activities (i.e. assignment) could offer 3.7 immediate assistance?

L2C Q3 Do you think the activities could improve the understanding of subject- 4 matter?

L2C Q4 Do you think the activities in online learning could improve your critical 3.9 thinking skills?

L2C Q5 Do you think you can use relevant knowledge wisely in the learning 4 process?

L2C Q6 Do you feel that the ease of online content is important? 4.2

L2C Q7 Do you feel that it is important to get an overview of the content before 4.2 the class begins?

L2C Q8 Do you think ODL gives more benefits than drawbacks? 3.8

Average Mean

4

\section{Conclusion}

\section{Summary of Findings and Discussion}

Results gathered from this study revealed high level of openness in online learning is displayed through learner-to-instructor engagement. The findings aligned with study conducted by Maphosa and Bhebhe (2020) whereby the researchers revealed that meaningful communication between the students and lecturers is crucial to reduce feelings of isolation among the students. Openness is demonstrated through openness to teaching and learning approaches as well as openness in communication among learners and instructors. This support the findings of this study in which a moderate high level of openness in online learning is displayed through learner-to-instructor engagement. Also, the result of this study showed that a moderate high level of connectedness in online learning is displayed through learner-to-content engagement. To illustrate this, Springer and Stone (2019) an effective digital resource must be accessible to all students and convenience to use to ensure the connectedness of students in ODL. 


\section{Pedagogical Implications}

With reference to Figure 2 again, the conceptual framework of this study which supported by Theory of Connectivism, this study proposes that openness in online learning is displayed through learner-to-learner engagement and learner-to-instructor engagement. Meanwhile, connectedness in online learning is displayed through learner-to-content engagement. To ensure the students having a high motivation during ODL, there is a need to establish the openness and connectedness in the learning session. They will have high satisfaction and participate actively during ODL if the ODL institutions and instructors emphasize these three engagements. Findings of this study suggest ODL institutions and instructors must put great effort to establish openness and connectedness in ODL learning session. Since online learning may be the learning approach in the future, there is a need to think the best approaches to enrich the connectedness and openness in the learning session. For instance, upgrading the learning content and learning method to be more online friendly and bridges the communication gaps among the learners and instructors.

\section{Suggestion for Future Research}

It is suggested that future research look into more efforts and initiatives to establish and sustain openness and connectedness in online learning. Future studies could also look at the impacts of having openness and connectedness towards the learners' performance. This is crucial to evaluate the successfulness of openness and connectedness demonstrated.

\section{References}

Adnan, M., \& Anwar, K. (2020). Online Learning amid the COVID-19 Pandemic: Students' Perspectives. Online Submission, 2(1), 45-51.

https://www.researchgate.net/publication/342355454_Online_learning_amid_the_C OVID-

19_pandemic_Students'_perspectives/link/5ef09e2192851ce9e7faf7e4/download

Ali, F. D. A. (2021). The Students' Perception on the Implementation of Online Distance Learning Among the Foundation Students of Universiti Selangor. Asian Journal of Research in Education and Social Sciences, 3(3), 177 -184. https://myjms.mohe.gov.my/index.php/ajress/article/view/15703

Allam, S. N. S., Hassan, M. S., Mohideen, R. S., Ramlan, A.F., \& Kamal, R. M. (2020). Online Distance Learning Readiness During Covid-19 Outbreak Among Undergraduate Students. International Journal of Academic Research in Business and Social Sciences, 10(5), 575-590.http://dx.doi.org/10.6007/IJARBSS/v10-i5/7236

Arslan, G. (2021). Loneliness, College Belonginess, Subjective Vitality, and Psychological Adjustment during Coronavirus Pandemic: Development of the College Belonginess Questionnaire. Journal of Positive School Psychology, 5(1), 17-31. https://www.researchgate.net/publication/344641534_Loneliness_College_Belonging ness_Subjective_Vitality_and_Psychological_Adjustment_during_Coronavirus_Pande mic_Development_of_the_College_Belongingness_Questionnaire

Aziz, W. N. H. W. A., Hasan, N. I. A., Hamzah, M. H. M., Aziz, R. W. A. (2020). Pearson Correlation Coefficient of the Student Perception and Challenges towards Open and Distance Learning During COVID-19, Mathematical Sciences and Informatics Journal, 1(1), 96-103. https://ir.uitm.edu.my/id/eprint/38995/

Chea, C. C., \& Huan, J. T. J. (2015). Using a Choice Experiment (CE) in an Open and Distance Learning (ODL) Context in Malaysia. Malaysian Journal of Distance Education, 17(1), 1- 
20. http://mjde.usm.my/vol17_1_2015/MJDE\%2017(1)\%202015\%20-\%20Art.\%201(120).pdf

Choudhury, B. R. (2018). Openness in Higher Education through Open and Distance Learning Environment. $5^{\text {th }}$ International Symposium on Emerging Trends and Technologies in Libraries and Information Services (ETTLIS). https://doi.org/10.1109/ETTLIS.2018.8485203

Chung, E., Noor, N. M. \& Mayyjew, V. N. (2020). "Are You Ready? An Assessment of Online Learning Readiness Among University Students." International Journal of Academic Research in Progressive Education \& Development, 9(1), 301-317. https://www.researchgate.net/profile/Norlina-Mohamed-

Noor/publication/341057343_Are_You_Ready_An_Assessment_of_Online_Learning_ Readiness_among_University_Students/links/5eab69fe45851592d6ae62a8/Are-YouReady-An-Assessment-of-Online-Learning-Readiness-among-University-Students.pdf

De Barba, P. G., Kennedy, G. E., \& Ainley, M. D. (2016). The Role of Students' Motivation and Participation in Predicting Performance in a MOOC. Journal of Computer Assisted Learning, 32(3), 218-2311. doi:10.1111/jcal.12130

Fauziah, S. (2015). Online Learning Conveniences from Students' Perception: A Case Study in Universiti Malaysia Sabah. International Journal of Humanities and Social Science Invention, 4(1), 1-5. https://d1wqtxts1xzle7.cloudfront.net/37416249/A04140105with-cover-page-v2.pdf?Expires $=1635244513 \&$ Signature $=$ OPyWI8M-

kwH1ulyAzCnEtebCnyAMzkN4pGvfRVGgTdcvTV9RZbbNc3912ICJ5oXJ9Ij6kJQFdgSrvrM Mi93eD4BoWTIza5W5IE0Xw7LIQICsdDtVZ5hUhxvCGR9vJaB9 tUU9RgFElecRBbFWB jS FQb-y9FrQHSiDggGTBQFHmjJ3p-JoFhMpN1KyHOzIFY4yplqYBKq2IPnS6WOFAhCG2kKk1-R-oiiWFrrvNHS334FpFVzvkb-OLH6kt0FFCnZAd7N-

RI9JsIYkw7FvUfUpWYaibtJgxdcVpnjyILDJ42WRijFNkMLy4AaJ4GBN7FYCu2FWatDrkDsP n8 ZgyQ_\&Key-Pair-Id=APKAJLOHF5GGSLRBV4ZA

Giesbers, B., Rienties, B., Tempelaar, D., \& Gijselaers, W. (2013). Investigating the Relations between Motivation, Tool Use, Participation, and Performance in an E-Learning Course using Web-Videoconferencing. Computers in Human Behaviour, 29(1), 285-292. doi:10.1016/j.chb.2012.09.005

Hashim, H., Kadir, N. A. A., Mansor, F., \& Azudin, M. Z. M. (2020). Open and Distance Learning (ODL_ During Movement Control Order (MCO). Conceptualising the Relationship between Self-Efficacy, Learning Motivation and Performance of Higher Learning Education Students. International Journal of Academic Research in Business \& Social Sciences, 10(8), 258-269. http://dx.doi.org/10.6007/IJARBSS/v10-i5/7236

Hehi, E., Zeller, M., Joanna, L., \& Chandler, T. (2021). Developing Student Connectedness under Remote Learning using Digital Resources: A Systematic Review. Education and Information Technologies. https://doi.org/10.1007/s10639-021-10577-1.

Irawan, A. W., Dwisona, D., \& Lestari, M. (2020). Psychological Impacts of Students on Online Learning During the Pandemic Covid-19. Jurnal Bimbingan dan Konseling (E-Journal). https://doi.org/10.24042/kons.v7i1.6389

Ismail, N. Z., \& Razak, M. R. (2021). The Challenges of Learning Programming Subject in Online Distance Learning (ODL) Environment at UiTM Pahang, Journal for Science and Technology, 4(2), 27-31.

Li, L.-Y., \& Tsai, C. C. (2016). Assessing Online Learning Material: Quantitative Behavior Patterns and Their Efforts on Motivation and Learning Performance, Computers \& Education, doi:10.1016/j.compedu.2017.07.007. 
Martin, F., \& Bolliger, D. U. (2018). Engagement Matters: Student Perceptions on the Importance of Engagement Strategies in the Online Learning Environment. Online Learning, 22(1), 205-222. http://doi.dx/ 10.24059/olj.v22i1.1092.

Martin, F., Wang, C., \& Sadaf, A. (2018). Student Perception of Helpfulness of Facilitation Strategies that Enhance Instructor Presence, Connectedness, Engagement and Learning in Online Courses. The Internet and Higher Education, 37, 52-65. https://www.sciencedirect.com/science/article/abs/pii/S1096751617301355

Maphosa, C., \& Bhebhe, S. (2020). Interrogating the Concept 'Openness' in Open Distance Learning (ODL). European Journal of Open Education and E-Learning Studies. 5(2), 3347. https://www.oapub.org/edu/index.php/ejoe/article/view/3282

Nunnally, J. C., \& Berstein, I. H. (1994). Psychometric Theory. $3^{\text {rd }}$ ed. New York, NY: McGrawHill

Ogirima, S. A. O., Arulogun, O. T., \& Osunniyi, J. S. (2020). Students Perspective Assessment on Adopting Open and Distance Learning in Nigeria: The Case Study of Ladoke Akintola University of Technology, Ogbomoso, Nigeria, International Journal of Scientific Research in Multidisciplinary Studies, 6(12), 27-34. https://www.researchgate.net/profile/Ogirima-

O/publication/350845780_Students_Perspective_Assessment_on_Adopting_Open_an d_Distance_Learning_in_Nigeria_The_Case_Study_of_Ladoke/links/6075b4e4a5c0b34 b72aced8d/Students-Perspective-Assessment-on-Adopting-Open-and-DistanceLearning-in-Nigeria-The-Case-Study-of-Ladoke.pdf

Rahmat, N. H., Sukimin, I. S. Sim, M. S. Anuar, M., \& Mohandas, E. S. (2021). Online Learning Motivation and Satisfaction: A Case Study of Undergraduates vs Postgraduates. International Journal of Asian Social Science, Asian Economic and Social Society, 11(2), 88-97. https://archive.aessweb.com/index.php/5007/article/view/3242

Ramlan, M., Maziah, M., Norhapizah, M. B., Hapini, A., Ponmalar, B. S., \& Fairuz, M. J. (2021). An Exploration on Online Learning Challenges in Malaysian Higher Education: The Post Covid-19 Pandemic Outbreak. International Journal of Advanced Computer Science and Applications. 12(7), 391 -398. https://www.researchgate.net/profile/RamlanMustapha/publication/353653434_An_Exploration_on_Online_Learning_Challenges_i n_Malaysian_Higher_Education_The_Post_COVID-

19_Pandemic_Outbreak/links/6108a1ef169a1a0103d43e95/An-Exploration-onOnline-Learning-Challenges-in-Malaysian-Higher-Education-The-Post-COVID-19Pandemic-Outbreak.pdf

Santosa, I., \& Riady, Y. (20210. Demotivating Factors of EFL Learners of Indonesian Undergraduate Students During Pandemic Covid-19: Gender Differences. Journal of Linguistics and Language Teaching. 7(1), 118-130. doi: 10.29300/ling.v7i1.4933

Stone, C., \& Springer, M. (2019). Interactivity, Connectedness and Teacher Presence: Engaging and Retaining Students Online. Australian Journal of Adult Learning, 59(2), 146-169. https://search.informit.org/doi/abs/10.3316/aeipt.224048

Siemen, G. (2005) Connectivism: A Learning Theory for the Digital Age. International Journal of Instructional Technology and Distance Learning, 2(1), Retrieved from http://www.itdl.org/Journal/Jan_05/article01.htm

Sim, S. P., Sim, H. P., \& Quah, C. (2020). Online Learning: A Post Covid-19 Alternative Pedagogy for University Students. Asian Journal of University Education, 16(4). 137 -151. https://myjms.mohe.gov.my/index.php/AJUE/article/view/11963 
Soetan, A. K., Udoh, G. M., \& Suleiman, Z. (2015). Problems and Prospects of Open and Distance Learning: A Case of the llorin Study Centre, Malaysian Journal of Distance Education, $17(1)$, 33-40. http://mjde.usm.my/vol17_1_2015/MJDE\%2017(1)\%202015\%20-\%20Art.\%203(3340).pdf

Wahab, N. A., Othman, J., Kadar, R., \& Warris, S. N. (2019). A Review of MOOCs Implementation in Malaysian Higher Education System, Journal of Computing Research \& Innovation, 4(2), $1-14$. https://crinn.conferencehunter.com/index.php/jcrinn/article/view/109

Wahid, H. S. A., Rahmat, N. H., Dzuradeen, N. S., \& Kadir, N. A. (2020) Are Students Engaging Online? European Journal of Education Studies, Vol 7(12), pp 202-221. Retrieved from https://oapub.org/edu/index.php/ejes/article/view/3408

$\mathrm{Yu}, \mathrm{C}$. (2015). Challenges and Changes of MOOC to Traditional Classroom Teaching Mode. Canadian Social Science, 11(1), 135 - 139. doi: 10.3968/6023 